\title{
Unlucky Political Strike, Spirit of Jihad and a New Church Building Plan \\ The Case of St Faustina Catholic Church Building Proposed in Bogor of Indonesia
}

\author{
Ibnu Hasan Muchtar ${ }^{1}$, Moh. Zaenal Abidin Eko Putro \\ \{ibnuhasan09@gmail.com ${ }^{1}$,zabiep@gmail.com ${ }^{2}$ \} \\ Research Center for Religious Society Guidance and Religious Service, MoRA of Indonesia ${ }^{1}$, Politeknik \\ Negeri Jakarta $(\mathrm{PNJ})^{2}$

\begin{abstract}
Building a new place of worship is a very sensitive issue in contemporary Indonesia, especially for religious minority community within different majority religious group. Rejection by some local residents who belong to different faith threatens the planned construction of a new worship place. The St. Faustina Kowalska Catholic Church 's license proposal in Kampung Tonjong, Tajur Halang, Bogor Regency is just one example. Frankly, the local government license was initially granted through Online Single Submission (OSS), but soon the name and number of the proposal no longer displayed. In fact, the Bogor regency had not given the permission yet. The authors attempt to investigate the case through a qualitative approach. To grab a deep understanding of the situation, the authors conducted several interviews with some prominent figures within the bureaucracy of Bogor Regency, ranging from the lower level, Tonjong 's head man to Bogor 's regent official. The research shows that, the cancelation of St. Faustina Kowalska Catholic church permit was due to the refusal from the opponent party of church building plan which had inspired by, among other things, the spirit of jihad. Basically, however, Bogor's regency government has shown a fast response to worship place permission by e.g. issuing some other worship place licenses that are not exclusively to church but other worship place too as long as there is no rejection from local citizens.
\end{abstract}

Keywords: place of worship, license proposal, local Muslim, government hesitation

\section{Introduction}

Building new worship place belongs to a religious minority community in some region of Indonesia has become a contentious issue. For the religious minority community, it is not unusual for those who want to create a new worship place such as mosque, church, temple, gurdwara, and other similar items to face certain difficulties because of the rejection by their various neighboring religious group. The case of Nur Musafirin of Batuplat Kupang (1) is only one example. It is not easy to enforce the new scheme detailing 90 users and 60 local neighbors' signature under the Joint Ministerial Regulation Between Religious Affairs Minister and Home Affairs Minister No 9 and 8, 2006. Local government, which is also under the current regulation, has an enormous obligation to resolve the dispute over the construction of new worship place, but they often do not have enough confidence to solve the issue. In 
reality, local government's responsibility is also to grant a license to construct new worship place at the end of the phase of building new worship place proposal.

Such a phenomenon occurs upon application for a license to build a new Catholic church in Tonjong village, Tajurhalang sub-district, West Java province Bogor Regency. The new church building committee, namely Santa Faustina Kowalska, has been running the plan by complying with the law. In 2014, they had started fulfilling the permitting process by collecting signatures from some Catholics who were the church consumer, as well as from local people listed above, before obtaining confirmation letters from neighborhood headman, village headman, and sub-district official. After that, they also received the recommendation letter from the Bogor Regency Ministry of Religious Affairs office and the recommendation letter from FKUB, or Interreligious Harmony Platform. The committee then submitted the proposal to the Bogor regency office along with all required documents which can be submitted through its online submission system. In fact, the local government's license was actually issued on the electrical permit system (called Online Single Submission -OSS) of Bogor Regency's one gate system authorization office in 2019, but soon the office's monitor screen suddenly no longer displays the church building plan proposal. In fact, the Bogor regency did not give the permission until recently.

The paper focuses on the Bogor regency local government 's refusal to issue a license for a new Catholic church in Tonjong village. The research question to be answered here is how the reluctance of such Bogor government to issue license letters happened in the new Catholic church in Tonjong village, while other new church licenses were successfully distributed in Bogor regency. As for example, according to Bogor regency data from the FKUB, a new Catholic church was issued in Bogor regency district of Jonggol and now the church itself has already established and fully run. Another question that needs to be discussed here is what happens if other worship religious developed without getting a local government license prior to that. Which government did for worship religious who were not previously approved by local government?

\section{Literature Review}

Indonesian government has issued Joint Regulation Between Minister of Religious Affairs and Minister of Home Affairs No 9 and 8 the year 2006 which outlines, among other things, the duty of the local leader in maintaining interreligious harmony, empowering interreligious harmony forum (FKUB) and giving recommendation of establishing a new place of worship as well. Its main and special aim is to minimize horizontal conflict caused by a place of worship establishment (2-4).

Prior to implementing the regulation, Indonesian government had introduced the joint Decree between the Minister of Religious Affairs and the Minister of Home Affairs (the joint Decree or SKB) Number 1/1969 to regulate religious activities and the construction of places of worship for all religious communities in Indonesia. Administered by the Ministry of Religious Affairs, Joint Decree 1/1969 granted the mayor / regent of the city / regency the responsibility to oversee and control religious activities to ensure that religious communities did not disrupt public peace and order (art.2). The local branch of the Ministry of Religious Affairs was also to track religious leaders and ensure that they did not denigrate other religions (art.3) (5). It can be found the parallels between PBM 9 \& 82006 and SKB 1/1969 
whereby local government must solve problems related with interreligious relation 'negative effect.

In Indonesia, social relations between various religious groups have become a very crucial issue in maintaining harmonious social life. Religious leaders traditionally play an important role in preserving unity by facilitating interfaith dialog and peace $(6,7)$. Interreligious peace, however, is challenged in some places when it comes to the place of worship debate $(8,9)$. For example, physical building of a church is a more complicated affair. It has been obligatory for all religions, including Christianity, since the Joint Ministerial Decree of 21 March 2006, which wishes to establish a place of worship to apply for a building permit or Izin Mendirikan Bangunan (IMB). The complexity of applying for IMB resulted in one of the distinguishing features of independent churches conducting their service in malls. Another factor independent churches are becoming increasingly relevant is their capacity to draw urban youth and young professionals (10).

As a matter of fact, rejection of a new worship place belonging to another community is often galvanized by the spirit of religious ideology known in Islam as the spirit of jihad (or ruhul jihad, Arabic). As stated earlier, the spirit of jihad also affects the rejection by local people of Tonjong village on new church plan. Then, what exactly does jihad mean? It is not easy to address that question because of the variety meaning of jihad this is a delicate matter. Yet jihad is one of the Islamic faith's most misunderstood principles, especially given its deadly significance in the fundamentalist movement. Jihad is closely associated with the early spread of Islam, today's debate about the origin and meaning of jihad is nothing less than a struggle over Islam itself. Jihad was first revealed in scriptures in the Koran that identified the Prophet Muhammad in his quest to establish a just egalitarian society in which poor and oppressed people were treated respectfully. In this context, jihad is perceived as a struggle or effort, not as a holy war which is an understandable misunderstanding of the West, considering that Islamic fundamentalists view themselves as such today. Jihad doesn't always mean Muslim and vice versa.

According to the hadiths, which are practices according to the Qur'an and the Prophet Muhammad, Jihad is the duty of every ruler, whether godly or evil, making it the moral duty of every real Muslim. Jihad is mainly stated in the Qur'an in relation to striving on God's path, and can be interpreted in two ways: moral striving and armed struggle, or greater jihad and lesser jihad, respectively. In the first part of the Koran, where Muhammad morally opposes the pagan rulers of the time with his faith during the Meccan period, jihad is represented as a moral striving. In this sense, jihad becomes a struggle inside to live a good Muslim life, following God's path. Some modern Muslims embrace the view of jihad, especially in terms of how they relate to the outside world. It is clear that this type of jihad is non-threatening to outsiders of Islamic faith, non-violence jihad, particularly the Western world, and focuses more on the improvement of the individual Muslim than on the Muslim community at large. The second concept of jihad as an armed struggle is described in the later chapters of the Koran that were written in Medina when Muhammad was the Muslims' political leader and fought for the establishment of an Islamic state with his military. First and foremost, jihad can only be fought against infidels, which translates into those who disbelieve in faith, and those who renounce faith, called apostates, hence the religious implications which lead non-Muslims to misinterpret the definition of jihad as a holy war. (11-14). 
The variety of opinions of experts on the meaning of jihad illustrates that the meaning of jihad itself is not only interpreted as a meaning that is identical to war. The various versions state that jihad is also defined as a serious effort in various activities which in the end is only one goal, namely to get the blessing of Allah SWT. Many opinions that always associate the meaning of jihad are always synonymous with acts of violence which will ultimately result in fighting and, furthermore, acts of war. That is what some opinions always mention that the meaning of jihad is the same as war on the battlefield. But if we observe further the meaning of jihad is even wider, it could mean trying desperately to exert all physical and material abilities in fighting and fighting the enemies of religion, earnestly or trying hard, struggling with all your might and earnestly to fight lust (fasting). in the month of Ramadan), against demons, and real enemies.

The mistake of understanding jihad as merely a physical struggle is caused by two things. First, the notion of jihad in particular is widely discussed in classical fiqh books and is always associated with wars, battles and military expeditions. This makes the impression, when Muslims read classical fiqh books, jihad only means war or physical struggle, nothing more than that. Second, the word jihad in the Koran appears at times of physical struggle / war during the Medina period, amidst the raging wars of Muslims defending their survival from attacks by the Quraish and their allies. This incised an understanding that jihad is closely related to war. Seeing the lack of education of the existing Indonesian people, in general there are not a few who consume the meaning of jihad at random without seeing any previous background elements. So that the impact of this gave birth to a different term and understanding of jihad. Today jihad is more often taken by many people to refer to the meaning of war, although in fact in the Qur'an the word is used not only in that sense.

If there is a group of Muslims who carry out a rebellion, which in the sense of opposing the policies of the majority of Muslims and maintaining their own opinion, but they are still obedient to the government, living in a Muslim country, then they should not be fought. The punishment for fighting these rebels is allowed if they disobey the government, are reluctant to fulfill their obligations as citizens, and enforce their own laws. The goal of fighting these rebels is to return them to the path of the majority of Muslims and to return to obeying the government. But again, that the use of violence is the last option. Dialogue is the first choice and action that must take precedence, so that bloodshed can be avoided. Besides, it is important to understand that the sword is incapable of conquering the heart. What is capable of opening and destroying the heart lock is with good, correct, and polite arguments, so as to satisfy the mind and melt the heart $(11,13)$.

Another thing besides the spirit of jihad which must also be regarded from the Muslim's point of view in the field of interreligious between Muslim and Christian is the long suspicious of what is called christianization. In her article entitled, Muslim-Christian Relationships in Indonesian Reform Era Within The Context of Democracy: Case Study of Bandung, Bekasi, and Bogor (1998-2015) in 2017, Damayanti notes that the number of Christian followers and the obscure number of Christian worship places raise concern and are viewed as a challenge by some Muslims to a greater extent. They opposed the so-called Christianization program implemented by the Indonesian and international churches and missionary organizations. Such a program of christianization triggers the Muslim hardliners' feelings of fear, and they respond accordingly to what they consider to be Christian provocation. They agree that they need to protect their religion and condemn any attempts to 
convert their Muslim relatives, even though the services offered for even a birthday celebration at a Christian's home (15-19).

Unlucky strike in political contestation means taking advantage of popular sentiment to underpin political position. Its forms are vary including the prevalence 'identity politics' that refers to social movements to gain recognition of historically oppressed ethnocultural or racialized groups. Historically, the politics of identity can be broadly categorized into two types: (1) politics of radical separatism, which involves a range of actions from violence to validation through conventional political means; and (2) identity politics under multiculturalism, through which minority and racialized groups seek recognition within pluralist societies. The first sets the challenge of understanding and opposing violence in a context of historical oppression. The second sets the challenge of going beyond practices of accommodation and difference to redefine the basis of citizenship (20-22).

\section{Research Method}

This paper is based on a qualitative approach designed to examine the basic details about something behind local government reluctance in granting a new church building license. The authors use three different techniques to collect the data, that is, observation, literature analysis and an in-depth interview. More precisely, observation is achieved by visiting the area where the new church is to be constructed. The study of literature is used to review many documents, including the documents from both the current church committee and local government. Interviews with main informants are also performed by interviewing some elite participants in the case such as FKUB Bogor regency chairman, Bogor regent deputy, Bogor regency ministry head of religious affairs and other leaders. The research itself was carried out in July 2020, second half.

\section{Result and Discussion}

In Bogor, the Catholic member grew smoothly in line with the fast-growing growth of the Bogor regency. Bogor regency is commonly considered to be a place where commuters who work in Jakarta live. It is possible to say that commuters are ethnically and religiously diverse because they work in cosmopolitan city, Jakarta. In the past, urbanization that resulted from the concentrated capital city of Jakarta allows for the situation of the variety of people employed in different government and non-governmental offices in the capital city of Jakarta.

As a result, the need for a worship place also rises in line with the mushrooming demand for new places to reside. As a result, the old built church no longer suffices to accommodate thousands of parishioners every Sunday to attend a mass ritual. The issue is evident in the case of the Tajurhalang parishioners and its some other associated subdistrict. It is not enough for them to do mass ritual in the current church at the present location. Moreover, the church they use themselves is not really a Catholic church, but an oikumene church situated at Tonjong village's Pura housing complex. For this purpose, they want to establish a new and their own church that accommodates Catholic members from at least three separate Bogor regency sub-districts, namely Bojonggede, Tajurhalang and Sukaraja. They intend to create a new church to cope with the problem by conforming to the state regulations (interview the authors with Fr. Endro of the parish of Santa Faustina Kowalska, 16 July, 2020). Also in the following days the writers had visited the church and noticed that the 
oikumene church was just a very simple structure. It does not have ample parking area as well as comfortable space for mass ritual services and other religious services.

Basically, the licensing process started in 2014 by seeking local community help for the construction of the Catholic Church of St. Faustina Kowalska located in Kampung Gunung Village, RT 001 RW 10 No. 4, Tonjong Village, Tajur Halang District, Bogor Regency, West Java Province. After three years of socializing the church building plan the committee received support from 101 signatories of supporters. The supporters signed it on a Rp6,000 seal to guarantee their support on the document, which contained that the supporters had no objection about the proposal. They accepted and funded the new Church building.

Then, on Monday 24 July 2017, a verification team from the Tonjong Village Office and Tajurhalang District held in the Tajurhalang District Office Hall checked the list of supporters and a statement message. Only 51 supporters could be legitimized after verification, according to the verification team, because only one supporter in one family was allowed under the verification plan. What is a bit confusing here, though, is why the supporters' signature is based on the family rather than the person mentioned on PBM No 9 \& $8 / 2006$. While feeling uncomfortable about the decision of the verification team, no objection from the committee concerning the decision, while they know it was odd and no longer in line with the law (interview with committee chair Darius on 16 July 2020). From now on the church building committee was asked to complete the lack of support to get 60 family signatories.

Next, on Tuesday, August 1, 2017, the verification team at the Tajurhalang District Office Hall checked the identity of some additional supporters suggested by the committee and counted a total of 14 persons (families). Thus the number of residents supportive became 65 families. After that, Tonjong Village officials conducted factual verification on Friday, August 25, 2017 by visiting the area where the church will be erected at Kampung Gunung, RT 001 / RW 10, Tonjong Village, Tajurhalang District. The Church users as well as the local supporters were also checked by the Verification team. It should be noted that it is mainly non-Muslims who reside in this rukun tetangga (RT, or Neighborhood Peace, a smallest neighborhood organization). Muslim is just about 40 percent, with the majority being a combination of several other sects. Chinese descendants also settle with a large number in this area (interview with the author at Citizen Harmony (RW) 10 Tonjong, Gunarto, July 17, 2020).

After that, on January 5, 2018, a meeting was held in Bogor Regency 's Hall of Kantor Kesatuan Bangsa dan Politik (Kesbangpol, or the Office of National Unity and Politics) to discuss the building of the St. Faustina Kowalska Catholic Church. The meeting resulted in two things, namely the declaration of full fulfillment of the necessary documents for the creation of the plan for the Church and the committee has proven to obtain letter of protection guarantee from the local apparatus. It was FKUB Bogor Regency which made its own standard operating procedure ( SOP) which says that before issuing the letter of recommendation, the committee of the new worship place must request a letter of protection guarantee from the local authorities, those who command the district area called musyawarah pimpinan kecamatan (Muspika, or district leader assembly) such as district governor, district police chief.

The Bogor Regency 's Ministry of Religious Affairs (Kantor Kementerian Agama Kabupaten Bogor) released its recommendations under number B 546 / Kk.10.01 / 
BA/02.2/01/2018 on 16 January 2018, being named as one of the responsible parties to issue a recommendation letter. Then Bogor Regency's Religious Harmony Forum (FKUB) issued a letter of recommendation with the number 022 / FKUB / Kab. Bogor II/2018, dated 28 February 2018.

After receiving recommendations from the Bogor Regency Ministry of Religious Affairs and the Bogor Regency FKUB, the St. Faustina Kowalska Catholic Church Building Committee submitted an application for a permit to the Regent of Bogor, through the Head of Dinas Penanaman Modal dan Pelayanan Terpadu Satu Pintu (Bogor Regency One Stop Investment and Integrated Service Agency). A meeting with the Government of Bogor Regency was then held at the Regional Secretary Meeting Room of Bogor Regency on 8 November 2018. The meeting was chaired by the Head of the Bogor Regency Secretariat's Public Welfare Section (Bidang Kesejahteraan Rakyat) and was attended by elements from the Tajurhalang District, Bojonggede Sub-District, Sukaraja Sub-District, as well as elements from the National Unity and Politics Office, Bogor Regency Ministry of Religious Affairs, FKUB Bogor Regency, Inve Secretary It was reported at the hearing session that the building of the St. Faustina Kowalska Catholic Church in Tonjong Village, which was submitted by the committee, was no longer having problems. Even the church committee had given a clear example of how to comply with the regulation in recommending a new worship place (committee document) to meet the procedures.

According to the committee's paper, on 3 January 2019, Dinas Penanaman Modal dan Pelayanan Terpadu Satu Pintu (Bogor Regency Investment Service and One Stop Integrated Service) broadcast the approval of the St. Faustina Kowalska Catholic Church Land Use Permit through its online system. It was released with the number: 591.2/002/01158 / DPMPTSP/2018 of 3 January 2019 and electrically signed on behalf of the Bogor Regent by Joko Pitoyo, Head of the One Stop Investment and Integrated Services Office. The message on the office's computer screen, however, soon deleted approval for new church building. Then, a new letter released by the new Head of Bogor Regency One Stop Investment and Integrated Service Service, Dace Supriadi with Number: 581/2068-PPR, dated 1 August 2019, requesting the Committee to complete some additional administrative requirements following the normal Operating Procedure of Bogor Regency FKUB as previously stated.

To meet the instruction, a letter from the Head of the Bojonggede Police Sector number B/109 / IX/2019 / Sek Bj gede, containing peace and public order not disturbing to the local community, was added by the Church Construction Committee. Then on 16 September 2019 the District Military Commander (Koramil 04 / Bojonggede) issued a similar declaration letter with the letter numbered B/43 / IX/2019.

Currently, following the completion of some additional necessary documents requested by the Dinas Penanaman Modal dan Pelayanan Terpadu Satu Pintu (Investment Service Office and One Stop Integrated Services), no further response has yet been received from the Bogor Regional Government regarding the issuance of a permit to build the new church.

\section{Rejection from Local Muslims}

According to Bogor Regency head of FKUB, Mad Roja Sukarta, the reasons why the Bogor regency has not approved a new place of worship are varying. One is that the local government is closely monitoring the local situation surrounding the planned new worship 
place. Local government delays the decision to accept the permit of a new worship place to prevent social tension between the community. This is what happened with the request of a new Catholic church in Tonjong village (Author interview, July 21, 2020).

Local government 's delay in issuing a license for the committee is due to an opposition letter from local people in 2017 from the new Catholic church in Tonjong village. Being organized by a man who is now deceased, serving at the central office of Badan Pertanahan Nasional (National Land Bureau) and a member of the Partai Keadilan Sejahtera (PKS, or Social Justice Party), more than 50 people sign on the letter of refusal. The main explanation was that the church would disrupt local people's faith and the story circulating was that the church that was to be founded is Southeast Asia's largest church. It was spread by public preaching, even during a wedding ceremony. And, the man mentioned earlier had organized people to sign the letter of refusal. Unpleasantly, the chief of the Tonjong village Majelis Ulama Indonesia (MUI, or Ulama Indonesian Council) also played an important role in persuading local people to sign on the letter of refusal. Feeling threatened with new church building plan calls for jihad spirit among the people who rejected the church (Interview of the authors with prominent informants who know the situation, August 2020).

This issue also comes to the head of Tajurhalang district's Majelis Ulama Indonesia (Ulema Indonesian Council), Dimyati, who thinks only time will change the situation. $\mathrm{He}$ himself knows very well that his organisation, since MUI is not a government agency, has little to do with the new place of worship submission. It is an association of the Islamic people. However, he was also approached by several people, including the man who was threatening local people to oppose the new church plan in Tonjong village. In opposing the new church proposal, he brings up the question of ruhul jihad (the spirit of jihad). He seems to just wait for the situation and not want to try to mediate the case (on July 29, 2020, he interviewed the authors with the head of MUI Tajurhalang district, Dimyati).

\section{Not Suitable for Political Advantages}

When the authors try to trace any leader link to some other Islamic hardliner group behind the letter of rejection, the response is uncertain. If a man named Djunaidi who provoked a letter of rejection had a member of the PKS, then the other signatories of rejection deal with him. According to local source, most Muslims in the village of Tonjong follow the Nahdlatul Ulama (NU). There is no other Islamic party in the society which can question NU. And no rally had occurred at all on the height of the letter of rejection mobilization. The only thing which questioned the new church building was the letter of rejection.

According to a source person who is one of Tonjong village 's former heads of rukun warga (citizen harmony group), the reason why the letter of rejection made Bogor 's government reluctant to grant a permit is because Tonjong 's head of MUI has a special link with the Bogor Regent. In addition, they are both member of the board of the same political party, Partai Persatuan Pembangunan (Development and Unity Party). The Regent of Bogor, Ade Yasin, is the PPP elite. It is possible to know that a special relation between MUI Tonjong 's head and the regent has brought the letter of rejection into particular consideration by the Bogor government.

This information has also been said by some Bogor government elite who have admitted that the Regent does not rush to grant a permit to the New Catholic Church committee in Tonjong because she wants to save her votes from her (constituent) supporter in 
the city. Henceforth, granting a permit to the church committee for the next local election would not give the regent any gain.

It should be remembered, however, that in terms of political gain, the near relation with the regent does not belong exclusively to the rejection party. In fact, according to the church committee president, Darius, Fr. Ade Yasin was also sponsored by Endro and him during the past election. P. D. Endro and him have also entered a meeting with Ade Yasin heading up the 2018 local election. But Darius doesn't want to make his plan to create a new church that joins the political arena. What the committee wants is simply to obey the legislation and to expect that the government can decide on the basis of the procedure set out in PBM No 9 \& 82006.

\section{Conclusion}

Pursuant to the Joint Ministerial Regulation (Peraturan Bersama Menteri) between the Minister of Religious Affairs and the Minister of Home Affairs No 9 and 8 2006, the mandatory provision detailing 90 users and 60 local neighbors is not easy to enforce. Local government has a huge power to do or not to do in granting a permit to build a new church, though FKUB has obtained a letter of recommendation from the committee. Any factors lead to the reluctance of the local authority to issue a license including consideration of the contribution to the local election for their political advantage. In a case of building a new Catholic church in Tonjong, however, what the committee wants is merely to obey the regulations and expect that the government can make decisions based on the procedure outlined in PBM No 9 \& 82006.

\section{Reference}

[1] Hutagalung SA. Muslim-Christian Relations in Kupang: Negotiating Space and Maintaining Peace. Asia Pacific J Anthropol. 2016;

[2] Adhan S. Suing The House of God: The Case OF Church Establishment in Pangkep Regency. Jicsa. 2017;06(01):175-218.

[3] Ruhana A. Peran Pemerintah Daerah dalam Pemeliharaan Kerukunan Beragama di Provinsi Kepulauan Riau. J Bina Praja. 2015;07(02):185-93.

[4] Sirait MOB, $\square$, Masrukhi S. Peran Forum Kerukunan Umat Beragama Dalam Mengembangkan Nilai Toleransi Di Kabupaten Bekasi. Unnes Civ Educ J. 2014;3(2):10-7.

[5] Crouch M. Implementing the regulation on places of worship in Indonesia: New problems, local politics and court action. Asian Stud Rev. 2010;34(4):403-19.

[6] Jubba H. RELIGIOUS VIOLENCE IN THE INDONESIAN DEMOCRATIC ERA. AL ALBAB. 2018;7(1):3-16.

[7] Zulkarnain Z, Samsuri S. Religious Leaders and Indonesian Religious Harmony. 2018;(January).

[8] Mujiburrahman. F E E L I N G T H R E AT E N E D M U S L I M - C H R I S T I A N R E L AT I O N S I N I N D O N E S I A' S N E W O R D E R [Internet]. Available from: https://openaccess.leidenuniv.nl/bitstream/handle/1887/10061/Dissertation Mujiburrahman.pdf?sequence $=1$

[9] Salim DP. Kerukunan Umat Beragama Vs Kebebasan Beragama Di Indonesia. Potret Pemikir. 2017;21(2). 
[10] Chong T. Singapore 21 February 2019 Independent Innovations Churches in Indonesia : Challenges. 2019;(8):1-7.

[11] Skinner K. Fundamentalism and Jihad. Rivier Acacemic J. 2007;3(1):1-7.

[12] Wiktorowicz Q. A genealogy of radical Islam. Studies in Conflict and Terrorism. 2005.

[13] Bonner M. Jihad in Islamic history: Doctrines and practice. Jihad in Islamic History: Doctrines and Practice. 2008.

[14] Cook D. Understanding Jihad. Understanding Jihad. 2005.

[15] Damayanti A. Muslim-Christian Relationships in Indonesian Reform Era Within The Framework of Democracy: Case Study of Bandung, Bekasi and Bogor (1998-2015). 2018;129(Icsps 2017):9-18.

[16] Watson Andaya B. Between empires and emporia: The economics of christianization in early modern Southeast Asia. J Econ Soc Hist Orient. 2010;

[17] Mubarok H. Babak Baru Ketegangan Islam dan Kristen di Indonesia. Stud Islam. 2015;

[18] Makin A. Islamic acehnese identity, Sharia, and christianization rumor: A study of the narratives of the attack on the bethel church in Penauyong Banda Aceh. J Indones Islam. 2016;

[19] Sukamto A, Pramono R. The Roots of Conflicts between Muslims and Christians in Indonesia in 1995-1997. Transformation. 2020;

[20] Kobayashi A. Identity Politics. In: International Encyclopedia of Human Geography. 2009.

[21] Bernstein M. Identity politics. Annu Rev Sociol. 2005;

[22] Castells M, Himanen P, Castells M, Himanen P. The Power of Identity. In: The Information Society and the Welfare State. 2011. 